\title{
Analisis Kualitas Pelayanan Rawat Jalan Pada Rumah Sakit Umum Daerah (RSUD) Kota Dumai
}

\author{
Hengky Krismanto ${ }^{1}$, Surya Irianto $^{2}$
}

\begin{abstract}
This research is a qualitative descriptive study, where qualitative descriptive research is used to describe a situation about the quality level of public hospital outpatient Services (RSUD) Dumai City. Judging from the number of patient visits, the outpatient continues to increase annually the number of visits in 2018 as many as 96,590 visits with an average of 334 patients on a daily basis while at 2017 as much as 87,922 visits with an average of 305 patients per day and a visit at 2016 as much as 79,129 with a day average visit of 275 patients. This research is done to find out how the quality of outpatient service in the District public Hospital (RSUD) Dumai. The purpose of this research is to determine the quality of outpatient service in the District public Hospital (RSUD) Dumai is seen from the aspects of tangible, reliability, responsiveness, assurance and empathy. In conclusion, research proves that the quality of outpatient services in the District public Hospital (RSUD) Dumai is considered less good, because there are still many complaints from patients and society. The results of this research are expected to be beneficial in improving the quality of service in the District public Hospital (RSUD) Dumai, to fit the expectations and vision, the mission of District public Hospital (RSUD) Dumai.
\end{abstract}

Keywords: Service Quality, Hospital, Public Service

\begin{abstract}
ABSTRAK
Penelitian ini adalah penelitian kualitatif deskriptif, dimana penelitian deskriptif kualitatif digunakan untuk menggambarkan suatu situasi tentang tingkat Kualitas Pelayanan Rawat Jalan Rumah Sakit Umum Daerah (RSUD) Kota Dumai. Dilihat dari jumlah kunjungan pasien, pasien rawat jalan terus mengalami peningkatan setiap tahunnya jumlah kunjungan yaitu pada tahun 2018 sebanyak 96.590 kunjungan dengan rata-rata 334 pasien berkunjungan sehari sedangkan pada 2017 sebanyak 87.922 kunjungan dengan rata-rata 305 pasien per hari dan kunjungan pada 2016 sebanyak 79.129 dengan kunjungan rata-rata sehari 275 pasien . Penelitian ini dilakukan untuk mengetahui bagaimana Kualitas Layanan Rawat Jalan di Rumah Sakit Umum Daerah (RSUD) Kota Dumai. Tujuan penelitian untuk mengetahui kualitas Layanan Rawat Jalan di Rumah Sakit Umum Daerah (RSUD) Kota Dumai dilihat dari aspek tangible, reliability, responsiveness, assurance dan empathy. Kesimpulannya, penelitian membuktikan bahwa kualitas Layanan Rawat Jalan di Rumah Sakit Umum Daerah (RSUD) Kota Dumai ternyata dianggap kurang baik, karena masih banyak keluhan dari pasien dan masyarakat. Hasil penelitian ini diharapkan dapat bermanfaat dalam meningkatkan kualitas pelayanan di Rumah Sakit Umum Daerah (RSUD) Kota Dumai, agar sesuai dengan harapan dan visi, misi Rumah Sakit Umum Daerah (RSUD) Kota Dumai.
\end{abstract}

\footnotetext{
${ }^{1}$ Sekolah Tinggi Ilmu Administrasi Lancang Kuning Dumai. Email : hengkykrismanto@gmail.com

${ }^{2}$ Sekolah Tinggi Ilmu Administrasi Lancang Kuning Dumai
} 
Kata Kunci : Kualitas Pelayanan, Rumah Sakit, Pelayanan Publik.

\section{PENDAHULUAN}

Dalam Undang-Undang Republik Indonesia No.25 Tahun 2009, Negara bertanggungjawab dalam melayani setiap warga negara dalam memenuhi hak serta kebutuhan mendasar dalam melaksanakan pelayanan publik yang merupakan pesan dalam UndangUndang Dasar Tahun 1945. Pelayanan Publik dikatakan juga sebagai kegiatan dalam rangka memenuhi kebutuhan dalam hal melayani sesuai dengan peraturan undang-undangan pada setiap warga negara terhadap barang, jasa atau pelayanan administrasi dan telah disediakan oleh penyelenggara pelayanan publik. Salah satu penyelenggara pelayanan publik dalam hal ini yaitu melaksanakan kegiatan pelayanan publik di bidang kesehatan. Persoalan kesehatan sudah menjelma menjadi kebutuhan yang sangat penting bagi warga Negara. Seluruh warga Negara membutuhkan pelayanan kesehatan disebabkan kesehatan dinilai berharga dan mahal. Kesehatan juga dikatakan juga merupakan bagian terpenting dalam kesejahteraan warga negara.

Untuk itu salah satu hak mendasar masyarakat ialah mendapatkan pelayanan kesehatan yang wajib diselenggarakan oleh pemerintah sebagaimana tercantum dalam Undang-undang 1945 pasal 28H ayat 1 yaitu "Setiap warga negara memiliki hakuntuk hidup yang sejahtera lahir \& batin, serta memiliki tempat tinggal, dan mendapat lingkungan hidup yg baik, sehat dan memiliki hak untuk memperoleh pelayanan kesehatan”.

Pelayanan kesehatan tidak hanya menyembuhkan penyakit tetapi dituntut untuk lebih memfokuskan pada kebutuhan pelanggan, sebagai upaya melaksanakan tuntutan masyarakat untuk mendapatkan pelayanan yang berkualitas, dan sesuai dengan fungsi pemerintah dalam melaksanakan serta meningkatkan pelayanan pada warga negara secara optimal, dengan meningkatkan mutu pelayanan di bidang kesehatan. usaha untuk meningkatkan derajat kesehatan yg setinggi mungkin pada awalnya yaitu usaha dalam menyembuhkan penyakit, lalu sedikit demi sedikit menuju ke arah Keterpaduan untuk memecahkan persoalan kesehatan untuk seluruh rakyat dan mengikut sertakan warga Negara dalam arti yang luas dapat dikatakan bentuk upaya promosi atau mengajak, pencegahan, pengobatan, dan pemulihan yg bersifat menyeluruh \& terus menerus. Undang Undang No 44 Tahun 2009 mengenai Rumah Sakit, diartikan bahwa Rumah Sakit adalah lembaga pelayanan jasa kesehatan yang menjalankan pelayanan secara lengkap dengan menyiapkan pelayanan instalasi rawat inap, instalasi rawat jalan \& instalasi gawat darurat. Dalam akhir Undang Undang tersebut dijelaskan bahwa Rumah Sakit merupakan sarana pelayanan kesehatan yang menjadi kesatuan dari sumber daya kesehatan yg penting dalam menunjang terselenggaranya pelayan kesehatan.

Proses pelayanan di Rumah Sakit mempunyai karakter yang sangat rumit. Karena pelayanan kesehatan dan seperangkat keilmuan saling berhubungan satu dengan yang lain. IPTEK dalam kedokteran sangat berkembang pesat dan wajib diikuti oleh tenaga kesehatan dalam menyelenggarakan pelayanan yang baik dan bermutu, sehingga menjadikan makin peliknya permasalahan pada Rumah Sakit.

Dalam usaha meningkatkan pelayanan perlu ditingkatkan pula mutu pelayanan yang diberikan, hal ini disebabkan semakin kompleksnya kebutuhan masyarakat akan 
kesehatan. Hal ini ditandai dengan semakin tingginya pendidikan dan sosial masyarakat, maka tuntutan akan pelayanan kesehatan yang baik semakin tinggi dan perlu juga lembagalembaga kesehatan untuk terus berusaha memberikan pelayanan dan meningkatkan kualitas pelayanan, menciptakan kualitas pelayanan. Pada pasal 29 huruf b UU Nomor. 44 Tahun 2009, disebutkan bahwa rumah sakit berkewajiban memberikan pelayanan kesehatan yang aman, bermutu, tidak deskriminatif serta berhasil guna, dan mengutamakan kebutuhan pasien sesuai dengan standar pelayanan yang ada di rumah sakit.

Mutu pelayanan kesehatan rumah sakit memiliki bebarapa unsur, yaitu memenuhi standar mutu pelayanan yang sudah diterapkan serta memenuhi kebutuhan terhadap kepuasan pelanggan. Terdapat hubungan erat antara kualitas pelayanan dengan kepuasan pelanggan/konsumen. Kualitas dapat membuat sesuatu dorongan terhadap konsumen/ pelanggan atau pasien dalam rumah sakit, agar dapat membuat suatu hubungan yang erat dengan rumah sakit. Dalam jangka panjang proses ikatan ini dapat membuat rumah sakit untuk lebih memahami harapan pasien dan kebutuhan yang mereka butuhkan. Dengan begitu, rumah sakit dapat mengetahui tentang tingkat kepuasan konsumen, dimana rumah sakit dapat memberikan pelayanan yang memuaskan yang pernah dialami konsumen dan meminimalisir pelayanan yang tidak diingikan yang dialami konsumen/masyarakat.

Rumah sakit wajib memberikan pelayanan berfokus terhadap kepuasan masyarakat, perbaikan kualitas pelayanan jasa kesehatan bisa diawali dengan memberikan penilaian pada setiap komponen yang berperan dalam menumbuhkan kepuasan pada pasien. Unsur-unsur yang berkaitan dengan kepedulian kesehatan bisa diperbaiki dengan tahapan yang berkaitan dengan pelayanan termaksud sudut pandang dari pasien seperti seberapa bagus pelayanan jasa kesehatan yang mereka butuh-kan dan inginkan.

Pelayanan kesehatan yang berkualitas adalah pelayanan yang dapat menumbuhkan rasa puas pada pemakai jasa pelayanan sesuai dengan tingkat kepuasan yang diinginkan masyarakat dan pelaksanaannya sesuai dengan norma dan standar pelayanan yang ditetapkan.

Kepuasan pasien merupakan nilai yang subjektif pada kualitas pelayanan yang diperoleh pasien dalam pelayanan jasa kesehatan. Penialaian subjektif ini amat dipengaruhi oleh pengalaman, pendidikan, tingkat emosional dan keadaan lingkunga, tingkat kepuasan pasien tetap didasarkan pada kenyataan yang objektif yang dialami pada saat pasien menerima pelayanan di rumah sakit. Kepuasaan adalah harapan yang sesuai dengan kinerja atau hasil yang dirasakan oleh seseorang.

Jadi dapat disimpulkan puas atau tidak puasnya seseorang/masyarakat terhadap pelayanan yang diberikan adalah adanya kecocokan interaksi antara harapan dan pengalaman sesudah memakai jasa atau pelayanan yang diberikan. Seiring dengan perkembangan zaman Tuntutan pasien akan kualitas pelayanan mengharuskan adanya perubahan pelayanan dari sudut pandang lama ke sudut pandang baru. Kebutuhan pasien sangat diutamakan sehingga pasien merasa terpuaskan akan setiap pelayanan yang mereka terima lalu kemudian dari kepuasan itu timbullah kesetiaan mereka sehingga membuat mereka tidak beralih ke rumah sakit umum lain.

Seiring dengan pesatnya perkembangan ilmu dan teknologi dibidang kesehatan serta semakin banyaknya jumlah rumah sakit dewasa inii membuat masyarakat mempunyai 
beberapa pilihan untuk menetapkan rumah sakit yang di anggap mereka bagus sebagai tempat untuk menerima pelayanan yang berkualiatas. Konsumen menetapkan pilihan rumah sakit yang diharapkan memberikan pelayanan yang baik serta memuaskan menurut mereka.

Pengurus rumah sakit seharunya lebih mengerti dengan kondisi tersebut sehingga dalam memberikan pelayanan selalu berorientasi pada harapan dan dapat memberikan kepuasan kepada konsumen agar bisa berlomba dengan rumah sakit lain.

Masyarakat yang menggunakan pelayanan dapat merasa terpenuhi kebutuhannya jika adanya kesesuaian antara harapan dan kenyataan dalam pelayanan yang diterima. Kepuasan masyarakat yang menggunakan jasa kesehatan memiliki keterkaitan yang erat dengan hasil pelayanan kesehatan yang diberikan, baik secara langsung dilayani tenaga kesehatan ataupun pelayanan yang diberikan secara tidak langsung, seperti taat dengan pengobatan yang di anjurkan tenaga kesehatan, mengerti dengan informasi medis yang diberikan dan kelanjutan perawatan.

Pemerintah kota Dumai Mendirikan Rumah Sakit Umum Daerah (RSUD) Kota Dumai pada tanggal 15 Februari 1999 Yang Diresmikan Oleh Bupati Bengkalis, Bapak Fadlah Sulaiman, SH. Pada Saat Kota Dumai Masih Berstatus Kota Administratif.

Tanggal 7 mei 1999 peresmian Dilaksanakan Oleh Menteri Kesehatan R.I Prof.DR.Dr. FA. Moeloek, SpOG, Berdasarkan Kepmenkes dan Kesejahteraan Sosial Nomor 1549/MenkesKesos/SK/X/2000. Tanggal 16 Tahun 2000. Tahun 2009 Rumah Sakit Umum Daerah (RSUD) Kota Dumai menjadi Rumah Sakit Badan Layanan Umum Daerah (BLUD) menurut Keputusan Walikota Dumai nomor
380/RSUD/2009, berhubungan dengan Penetapan Status Rumah Sakit Umum Daerah (RSUD) Kota Dumai. Hal ini sesuai persyaratan undang-undang Republic Indonesia nomor 44 Tahun 2009 perihal Rumah Sakit, menurut Bab 5 Pasal 7 Ayat 3.

Pada tahun 2018 Rumah Sakit Umum

Daerah Kota Dumai Memperoleh Izin Operasional Rumah Sakit jenis B, Berdasarkan Keputusan Kepala Dinas Penanaman Modal Dan Pelayanan Terpadu Satu Pintu Provinsi Riau nomor: 503/DPMPTSP/IZIN-KES/97. Sesuai dengan Permenkes Republik Indonesia No 56 Tahun 2014 perihal pengelompokan dan perizinan Rumah Sakit Umum Pemerintahan dikelompokkan ddalam beberapa tingkatan yaitu Rumah Sakit Umum jenis A, Rumah Sakit Umum jenis B, Rumah Sakit Umum jenis C, Rumah Sakit Umum jenis D. Penetapan klasifikasi Rumah Sakit berdasarkan pelayanan yang diberikan, sumber daya, peralatan, saran dan prasarana dan administrasi serta manajemen Rumah Sakit Umum Daerah (RSUD) Kota Dumai.

Dalam menjalankan pelayanan kesehatan Rumah Sakit Umum Daerah (RSUD) Kota dumai mempunyai VISI yaitu : "Mewujudkan Rumah Sakit Pendidikan Di Pantai Timur Sumatera"

Untuk mendukung Visi Rumah Sakit Umum Daerah (RSUD) Kota Dumai tidak terlepas adanya Misi Rumah Sakit Umum Daerah (RSUD) Kota Dumai yaitu:

1. Menerapkan sendi-sendi pelayanan prima.

2. Meningkatkan profesionalitas sumber daya manusia.

3. Meningkatkan sarana dan prasarana pelayanan.

4. Menjalankan fungsi manajerial yang akuntabel dan transparan, berbasis teknologi informasi. 
Rumah Sakit Umum Daerah (RSUD) Kota Dumai adalah badan yang melaksanakan pelayanan di bidang jasa kesehatan yang terdapat di Kota Dumai. Rumah sakit ini merupakan milik Pemerintah Daerah dan rumah sakit ini adalah rumah sakit yang menjadi salah satu rumah sakit acuan di Kota Dumai, sehingga diharapkan dapat memberi pelayanan bermutu selaras dengan harapan masyarakat yang menggunakan pelayanan rumah sakit, tidak hanya jasa kesehatan yang bersifat penyembuhan, rumah sakit juga diharapkan dapat menimbulkan rasa puas pada pasien. Oleh sebab itu harus ada tanggapan mengenai pelayanan dari pasien atau masyarakat sebagai pemakai pelayanan.

Nantinya diharapkan berpengaruh baik pada peningkatan kualitas pelayanan pada rumah sakit dan juga sangat berpengaruh pada peningkatan kepuasan pasien dan masyaraka yang menggunakan pelayanan. Berdasarkan Perwa No. 42 Tahun 2008 Ayat 2 Pasal 2 \& 3 mengenai tupoksi tata kerja Rumah Sakit Umum Daerah Kota Dumai.

\section{Perwa No. 42 Tahun 2008 Ayat 2 Pasal 2:}

"Rumah Sakit Umum Daerah Kota Dumai memiliki kewajiban menyelenggarakan upaya kesehatan dengan efektif \& efisien serta mengutamakan upaya penyembuhan dan pemulihan yang dilaksanakan secara selaras, terpadu dalam peningkatan serta pencegahan dan melaksanakan upaya rujukan, sesuai dengan peraturan perundang-undangan yang berlaku”.

Perwa No. 42 Tahun 2008 ayat 2 Pasal 3 :

Untuk menjalankan tugas yang dimaksud pada pasal 2, Rumah Sakit Umum Daerah memiliki fungsi :
1. Penyelenggaraan pelayanan medis

2. Penyelenggaraan pelayanan penunjang medis dan non medis.

3. Penyelenggaraan pelayanan asuhan keperawatan.

4. Penyelenggaraan pelayanan rujukan.

5. Penyelenggaraan pendidikan dan pelatihan

6. Penyelenggaraan penelitian dan pengembangan.

7. Penyelenggaraan pengelolaan administrasi dan keuangan.

RSUD Kota Dumai memiliki beberapa pelayanan kesehatan salah satunya pelayanan Rawat Jalan. Pelayanan Rawat Jalan merupakan pelayanan kesehatan yang diberikan kepada pasien/masyarakat yang pelayanannya tidak melebihi dari 24 jam pelayanan yang diberikan bertujuan untuk pengamatan, diagnosis, pengobatan, pemulihan, serta pelayanan kesehatan lainnya, tanpa mewajibkan pasien untuk di rawat inap.

RSUD Kota Dumai memiliki beragam pelayanan pada poliklinik rawat jalan dari Klinik Anak, Klinik Interne, Klinik Kebidanan, Klinik Bedah, Klinik Umum, Klinik Gigi Mulut, Klinik VCT, Klinik Gigi Anak, Klinik Mata, Klinik Saraf, Klinik THT, Klinik Orthopedi, Klinik Bedah Mulut, Klinik Kulit dan Kelamin, Klinik Jiwa/Psikiatri, Klinik Paru-Paru, Klinik Kardiologi, Klinik Bedah Syaraf, Klinik Fisioterapi. Berikut data jumlah pasien Rawat Jalan 3 tahun terakhir di Rumah Sakit Umum Daerah (RSUD) Kota Dumai

Tabel 1.1

Jumlah Kunjungan Pasien Rawat Jalan
pada Rumah Sakit Umum Daerah (RSUD)
Kota Dumai Tahun 2016-2018




\begin{tabular}{|c|c|}
\hline Tahun & Rawat Jalan \\
\hline 2016 & 79.129 \\
\hline 2017 & 87.922 \\
\hline 2018 & 96.590 \\
\hline
\end{tabular}

Sumber: RSUD Kota Dumai 2019

Berdasarkan tabel 1.1 diketahui bahwa jumlah kunjungan pasien Rawat jalan pada Rumah Sakit Umum Daerah (RSUD) Kota Dumai terus mengalami peningkatan pada 3 tahun terakhir. Kenaikan kunjungan pasien tertinggi terlihat pada tahun 2018 sebanyak 96.590 pasien.

Kenaikan jumlah pasien setiap tahunnya menunjukkan belum sesuainya harapan pemerintah dalam memberikan pelayanan kesehatan yang baik dan bermutu, hal ini harus ditanggapi bijak oleh pemerintah maupun manajemen RSUD Kota Dumai. Berdasarkan data ini semua perlu adanya tindakan atau kebijakan pemerintah agar RSUD Kota Dumai menjadi lembaga pelayanan kesehatan yang bermutu serta mampu memberikan kepuasan kepada pasien.

Harapan masyarakat selaku pelanggan tentang kualitas pelayanan rumah sakit belum sepenuhnya terpenuhi, hal tersebut dapat dilihat berdasarkan pengamatan yang penulis lakukan, penulis mendapati berbagai masalah pertama terkait dalam proses pelayanan kesehatan rawat jalan saat memberikan pelayanan kepada kepada pasien/masyarakat.

Berdasarkan wawancara dan observasi yang sudah penulis lakukan dengan beberapa narasumber selaku masyarakat pengguna layanan rawat jalan di RSUD Kota Dumai, terdapat beberapa permasalahan yaitu Waktu tunggu merupakan salah satu masalah yang sering menimbulkan keluhan pasien di rumah sakit Umum daerah kota dumai.
Menurut Bapak Wan 60 tahun berobat di poli syaraf beliau mengatakan "saya datang dari jam 6 pagi untuk ambil nomor antrian dilayani di bagian pedaftaran jam 7, agak lama saya menunggu karena nomor antrian saya nomor 72 dan pendaftaran memanggil nomor itu 10 orang setiap beberapa menit, dokter juga lama datangnyaa, saya baru dilayani jam 11, saran saya untuk rumah sakit agak dipercepat pelayanan nya biar masyarakat tidak kelamaan menunggu” (Wawancara dengan Bapak Wan Pada 9 December 2019 pukul 11.50 WIB).

Selanjutnya Penulis juga melakukan wawancara dengan Kepala Ruangan Rawat Jalan yaitu Bapak Teguh beliau mengatakan "Keluhan yang sering saya terima dari masyarakat yang menggunakan rawat jalan memang dari antrian pendaftaran yang lama dan juga waktu menunggu pasien menerima pelayanan dari dokter yang lama (wawancara dengan Bapak Teguh Pada 11 December 2019 pukul 10.00 WIB).

Waktu tunggu pelayanan kesehatan merupakan hal yang penting dalam menentukan kualitas pelayanan rumah sakit. Berdasarkan Kepmenkes Nomor 129 tahun 2008 dalam pelayanan rawat jalan indicator waktu tunggu pelayanan di rawat jalan yaitu $\leq$ 60 menit dimulai pada saat pasien mendaftar hingga dilayani oleh dokter spesialis. Dan Masih ditemukan pegawai yang Kurang ramah terhadap pasien berdasarkan wawancara kepada pengunjung rawat jalan.

Menurut ibuk ana yang memeriksakan dirinya dirawat jalan poliklinik internet/ penyakit dalam beliau mengatakan "perawat/ pegawai yang ada dirawat jalan ini sudah cukup ramah dengan masyarakat yang memeriksakan dirinya ke poliklinik cukup komunikatif dalam melayani meskipun banyaknya orang yg memeriksakan dirinya 
dipoliklinik, keluhan saya hanya pada saat memarkirkan kendaraan, saya kerepotan saat parkir kendaraan karena tempat parkir tidak luas dan susah untuk memarkirkan kendaraan" (wawancara dengan Ibu Ana Pada 11 December 2019 pukul 10.40 WIB).

Kualitas pelayanan kesehatan di sebuah rumah sakit dapat diketahui dari profesionalitas tenaga medis maupun pegawai lainnya, efisien serta efektifnya pelayanan serta terpenuhinya harapan pasien saat menerima pelayanan pada rumah sakit. Kesesuaian antara harapan dan kenyataan terhadap pelayanan yang diterima pasien dapat dilihat dari seluruh manajemen pelayanan mulai dari administrasi, dokter, perawat, farmasi, sarana dan prasarana rumah sakit.

Kualitas pelayanan adalah aspek yang sangat penting dalam menumbuhkan kepercayaan pasien/masyarakat terhadap rumah sakit agar tercipta loyalitas mereka. Tersedianya perlengkapan kedokteran, kompetensi dan keterampilan tenaga medis maupun non medis, serta kesinambungan sistem pelayanan yang baik, serta terjaminnya kualitas yang diberikan adalah salah satu alasan mengapa masyarakat lebih memilih pelayanan rumah sakit diluar negeri dan menjadikannya pilihan dari pada rumah sakit di dalam negeri. Rumah Sakit Umum Daerah Kota (RSUD) Kota Dumai sebagai rumah sakit yang berstatus Badan Layanan Umum Daerah (BLUD) berusaha memperbaiki mutu pelayanan kesehatan kepada masyarakat agar dapat menjadi rumah sakit yang memenuhi harapan masyarakat, dalam hal pelayanan rawat inap maupun rawat jalan. Dengan peningkatan kualitas pelayanan berarti harus memenuhi standar waktu yang ditetapkan, tempat, biaya, prosedur yang ditetapkan untuk menyelesaikan setiap tugas dalam pemberian pelayanan serta dapat memuaskan pelanggan dengan biaya ter-jangkau, dan cepat sehingga masyarakat sebagai penerima layanan merasa puas.

\section{KAJIAN TEORI DAN HASIL PENELITI- AN TERDAHULU YANG RELEVAN}

Menurut Ibrahim dalam Hardiansyah (2018:22), kualitas pelayanan publik merupakan keadaan dinamis yang berhubungan dengan produk, jasa, manusia, proses dan lingkungan serta penilaian kualitas ditentukan pada saat terjadinya pemberian pelayanan tersebut.

Ciri atau atribut tersebut menurut Tjiptono dalam hardiyansyah (2011:40) antara lain adalah:

1. Ketepatan waktu pelayanan, yang meliputi waktu tunggu dan waktu proses;

2. Akurasi pelayanan, yang meliputi bebas dari kesalahan;

3. Kesopanan dan keramahan dalam memberikan pelayanan;

4. Kemudahan mendapatkan pelayanan, misalnya banyaknya petugas yang melayani dan banyaknya fasilitas pendukung seperti komputer;

5. Kenyamanan saat memperoleh pelayanan, berkaitan dengan lokasi, ruang tempat pelayanan, tempat parkir, ketersediaan informasi dan lain-lain;

6. Atribut pendukung pelayanan lainnya seperti ruang tunggu ber-AC, kebersihan dan lain-lain.

Menurut Tjiptono (2016:59) Kualitas Pelayanan adalah tingkat keunggulan yang diharapkan dan pengendalian atas tingkat keunggulan tersebut untuk memenuhi keinginan pelanggan.

Tjiptono (2016:121) Kualitas pelayanan sebagai ukuran seberapa bagus 
tingkat layanan yang diberikan mampu sesuai dengan ekspetasi pelanggan.

Menurut Goetsch \& Davis dalam Hardiansyah (2018:49). Kualitas pelayanan adalah merupakan kondisi dinamis yang berhubungan dengan produk, jasa, manusia, proses dan lingkungaan yang memenuhi atau melebihi harapan.

Hardiansyah (2018:49) Kualitas pelayanan adalah pelayanan yang diberikan keapada pelanggan sesuai dengan standar pelayanan yang telah dibakukan sebagai pedoman dalam memberikan layanan.

Gasperz dalam Sinambela (2008:7) mengemukakan bahwa pada dasarnya kualitas mengacu pada pengertian pokok:

1. Kualitas terdiri atas sejumlah keistimewaan produk, baik keistimewaan langsung, maupun keistimewaan atraktif yang memenuhi harapan pelanggan dan memberikan kepuasan pada penggunaan produk.

2. Kualitas adalah segala sesuatu yang bebas dari kekurangan atau kerusakan.

Zeithaml dalam Mukarom (2015: 109) mengemukakan sepuluh dimensi yang harus diperhatikan dalam tolak ukur kualitas pelayanan publik, yaitu:

1. Tangible, terdiri dari fasilitas fisik, peralatan, personel dan komunikasi;

2. Realiable, terdiri atas kemampunan unit pelayanan dalam menciptakan pelayanan yang dijanjikan dengan tepat;

2. Responsiveness, kemampuan untuk membantu konsumen bertanggung jawab pada kualitas pelayanan yang diberikan;

3. Competence, tuntutan yang dimilikinya, pengetahuan dan keterampilan yang baik oleh aparatur dalam memberikan pelayanan;
4. Courtesy, sikap atau perilaku ramah, bersahabat, tanggap terhadap keinginan masyarakat serta mau melakukan kontak atau hubungan pribadi;

5. Credibility, sikap jujur dalam upaya menarik kepercayaan masyarakat;

6. Security, pelayanan harus bebas dari berbagai bahaya dan risiko;

7. Access, adanya kemudahan untuk mengadakan kontak dan pendekatan;

8. Communication, kemauan pemberi pelayanan untuk mendengarkan suara, keinginan atau aspirasi pelanggan, sekaligus kesediaan untuk selallu menyampaikan informasi baru kepada masyarakat; dan

9. Understanding the costumer, melakukan segala usaha untuk mengetahui kebutuhan pelanggan.

Selanjutnya, Lovelock dalam Hardiansyah (2018:52) mengemukakan lima aspek yang harus diperhatikan bagi penyelenggaraan pelayanan publik, yaitu meliputi:

1. Tangible (terjamah) seperti kemampuan fisik, peralatan, personil dan komunitas material

2. Realiable (handal), kemampuan membentuk pelayanan yang dijanjikan dapat tepat dan memiliki keajegan.

3. Responsiveness. Rasa tanggung jawab terhadap mutu pelayanan

4. Assurance (jaminan), pengetahuan, perilaku dan kemampuan pegawai.

5. Empaty, perhatian perorangan pada pelanggan.

\section{METODE PENELITIAN}

Metode penelitian adalah kualitatif deskriptif yang hanya menganalisis dan menggambarkan Kualitas Pelayanan Rawat 
Jalan pada Rumah Sakit Umum Daerah Kota Dumai. Penelitian ini menggunakan pendekatan deskriptif naturalistik merupakan pendekatan yang menggambarkan gejala dan fakta yang terdapat di lokasi yang diteliti secara menyeluruh dan berdasarkan dengan kenyataan dalam pelayanan yang diberikan oleh petugas Rumah Sakit lalu dianalisis dengan teori yang dipilih. Penelitian ini dilakukan di rawat Jalan Rumah Sakit Umum Daerah Kota Dumai. Responden adalah seluruh objek penelitian. Responden dalam penelitian ini berguna untuk mendapatkan data/informasi ketika pasien dilayani di Rawat Jalan Rumah Sakit Umum Daerah Kota Dumai, terutama dalam pelayanan yang diberikan petugas Rumah Sakit Umum Daerah Kota Dumai, kepada pasien yang datang memeriksakan diri dirawat jalan.

Dalam penelitian ini yang menjadi narasumber adalah pasien/masyarkat yang datang untuk memeriksakan diri di rawat jalan pada Rumah Sakit Umum Daerah Kota Dumai pada saat peneliti melakukan penelitian, . Informan dalam penelitian ini sebanyak 8 Orang, sebagai berikut : Kepala Ruangan Rawat Jalan 1, Perawat 1 orang, dan Pasien rawat Jalan Rumah sakit Kota Dumai sebanyak 6 orang. Penelitian ini menggunakan data sekunder diperoleh dari literatur, jurnal ilmiah, dan dari bidang pelayanan Rumah Sakit Umum Daerah Kota Dumai.

Data ini digunakan sebagai data pendukung. Data primer merupakan data yang dihasilkan dari data yang dikumpulkan dilapangan. Data yang dikumpulkan didapatkan melalui cara: Tanya jawab, pengamatan dan dokumentasi. analisis data yang digunakan dalam penelitian ini menggunakan analisis dikemukakan oleh Miles dan Huberman dalam Hamid Patilima
(2007:100), yaitu meliputi: Reduksi data, Penyajian data, Menarik kesimpulan.

\section{HASIL DAN PEMBAHASAN}

\section{Dimensi Tangibel (Berwujud)}

Kemampuan Rumah Sakit Umum Daerah (RSUD) Kota Dumai menunjukan keberadaanya kepada masyarakat yang datang, keadaan lingkungan sarana dan prasarana adalah kemampuan rumah sakit dalam melakukan pelayanan yang diberikan oleh para petugas Rumah Sakit Umum Daerah (RSUD) Kota Dumai dalam melayani masyarakat atau pasien yang datang untuk memeriksakan diri dirawat jalan Rumah Sakit Umum Daerah (RSUD) Kota Dumai. Kepuasan pasien terhadap pelayanan yang diberikan diketahui dari jawaban pasien saat melakukan penelitian melalui wawancara dan observasi dilapangan.

Menurut yang memeriksakan dirinya dirawat jalan poliklinik internet/penyakit dalam beliau mengatakan "perawat/pegawai yang ada dirawat jalan ini sudah cukup ramah dengan masyarakat yang memeriksakan dirinya ke poliklinik cukup komunikatif dalam melayani meskipun banyaknya orang yg memeriksakan dirinya dipoliklinik, keluhan saya hanya pada saat memarkirkan kendaraan, saya kerepotan saat parkir kendaraan karena tempat parkir tidak luas dan susah untuk memarkirkan kendaraan” (wawancara dengan Ibu Ana Pada 11 Desember 2019 pukul 10.40 WIB).

Hasil observasi serta wawancara yang peneliti lakukan terlihat sarana dan prasarana di Rumah Sakit Umum Daerah (RSUD) Kota Dumai belum bisa dikatakan sesuai dengan standar pelayanan rumah sakit tipe $B$, dan dirasakan belum dapat dikatakan sebagai rumah sakit rujukan tertinggi terlihat dari lahan parkir yang kurang luas sehingga 
menyusahkan masyarakat untuk memarkirkan kendaraannya. Selain itu kurangnya kesadaran yang dimiliki oleh pendamping pasien dalam menjaga kebersihan dan sarana dan prasana yang telah disediakan serta belum lengkapnya tenaga kesehatan seperti dokter specialis.

Berdasarkan apa yang penulis temukan saat observasi dilapangan, dilihat dari aspek tangible belum sesuainya Rumah Sakit Umum Daerah (RSUD) Kota Dumai dengan standar untuk rumah sakit tipe $B$ terlihat dari lahan parkir yang sempit untuk masyarakat dan WC yang disediakan kurang terawat kebersihannya, sedangkan petugas yang melayani obat di apotik sudah cukup baik, obat yang diresepkan sebagian ada di apotek dan Dokter spesialis yang menangani pasien cukup lengkap tetapi belum sesuai dengan standar untuk rumah sakit tipe B dan perlu ada tambahan pada personilnya. Dapat dilihat jumlah dokter spesialis pada tabel berikut:

\begin{tabular}{|c|c|c|c|}
\hline No & Jenis Tenaga Kesehatan & $\begin{array}{c}\text { Jumlah Tenaga Kesehatan } \\
\text { pada RSUD Kota Dumai }\end{array}$ & $\begin{array}{c}\text { Peraturan Menteri } \\
\text { Kesehatan Republik } \\
\text { Indonesia No.56 Tahun } \\
2014 \text { RSUD Tipe B }\end{array}$ \\
\hline 1 & Doker Umum & 27 & 12 \\
\hline 2 & Dokter Gigi & 2 & 3 \\
\hline 3 & Spesialis Penyakit Dalam & 3 & 3 \\
\hline 4 & Spesialis Anak & 3 & 3 \\
\hline 5 & Spesialis Bedah & 5 & 3 \\
\hline 6 & Spesialis Obgin & 4 & 3 \\
\hline 7 & Spesialis Anestesiologi & 1 & 2 \\
\hline 8 & Spesialis Radiologi & 2 & 2 \\
\hline 9 & Spesialis Patologi Klinik & 1 & 2 \\
\hline 10 & Spesialis Patologi Anatomi & 2 & 2 \\
\hline 11 & Spesialis Rehabilitasi Klinik & Tidak Ada & 1 \\
\hline 12 & Spesialis Mata & 2 & 1 \\
\hline 13 & Spesialis THT & 2 & 1 \\
\hline 14 & Spesialis Syaraf & 1 & 1 \\
\hline 15 & $\begin{array}{l}\text { Spesialis Jantung dan } \\
\text { Pembuluh Darah }\end{array}$ & 1 & 1 \\
\hline 16 & Spesialis Kulit dan Kelamin & 1 & 1 \\
\hline 17 & Spesialis Kedokteran Jiwa & 1 & 1 \\
\hline 18 & Spesialis Ilmu Penyakit Paru & 2 & 1 \\
\hline 19 & Spesialis Orthopedi & 1 & 1 \\
\hline 20 & Spesialis Urologi & Tidak Ada & 1 \\
\hline 21 & Spesialis Bedah Plastik & Tidak Ada & 1 \\
\hline 22 & Spesialis Bedah Forensik & Tidak Ada & 1 \\
\hline 23 & Spesialis Bedah Mulut & 1 & 1 \\
\hline 24 & $\begin{array}{l}\text { Spesialis } \\
\text { Konservasi/Endodonsi }\end{array}$ & Tidak Ada & 1 \\
\hline
\end{tabular}




\begin{tabular}{|c|l|c|c|}
\hline 25 & Spesialis Orthodonti & Tidak Ada & 1 \\
\hline 26 & Apoteker & 42 & 12 \\
\hline 27 & Perawat dan Bidan & 356 & 282 \\
\hline
\end{tabular}

Sumber: RSUD Kota Dumai 2019

Seperti yang dikatakan Azwar (2002:5) rumah sakit merupakan lembaga pelayanan jasa kesehatan yang rumit, padat karya dan padat modal. Kerumitan ini muncul karena pelayanan pada rumah sakit melibatkan berbagai fungsi pelayanan, disiplin ilmu dan penelitian. Pelayanan dirumah sakit makin dituntut kualitas pelayanannya, dikarenakan per-kembangan masyarakat terus berubah dan maju, maka rumah sakit pemerintah berstandar tipe B merupakan rumah sakit dengan sarana prasana serta memiliki keahlian pelayanan medik spesialistik dasar.

Menurut Hartono (2010:3) rumah sakit merupakan sarana kesehatan yang menyelenggarakan pelayanan kesehatan secara merata, serta mengutamakan penyembuhan penyakit dan pemulihan kesehatan dan pencegahan penyakit dalam suatu sistem rujukan serta dapat digunakan sebagai tempat praktek pendidikan tenaga kesehatan dan penelitian.

Dapat penulis simpulkan bersumber pada data yang didapat dengan dikaitkan pada teori, dimensi tangible pada Rumah Sakit Umum Daerah (RSUD) Kota Dumai masih belum memenuhi standar.

Rumah Sakit Umum Daerah (RSUD) Kota Dumai belum dapat dikatakan standar selaku rumah sakit rujukan dalam memberi pelayanan, disebabkan sarana serta prasarana seperti lahan paskir untuk masyarakat yang sangat terbatas, serta jumlah petugas terutama dokter spesialis yang harus di lengkapi, kualitas petugas yang belum profesional serta ke-cakapan pihak manajemen dalam mengelola rumah sakit belum maksimal.
Dari hasil wawancara bersama informan berhubungan pada pengamatan dilapangan yang penulis lakukan serta teori yang berhubungan pada dimesi tangible, penulis menarik kesimpulan bahwa kualitas pelayanan rawat jalan pada Rumah Sakit Umum Daerah(RSUD) Kota Dumai dari dimensi tangible belum dapat dikatakan baik, di-sebabkan fasilitas sarana dan prasarana, serta petugas yang melakukan pelayanan belum lengkap dan belum memenuhi syarat rumah sakit tipe $\mathrm{B}$.

\section{Dimesi Reliability (Kehandalan)}

Dimensi reliability disini membuktikan dan menggambarkan kemampuan Rumah Sakit Umum Daerah(RSUD) Kota Dumai saat memberi pelayanan sesuai dengan harapan masyarakat seperti keakuratan diagnosa, keakuratan resep dokter, serta kesungguhan perawat dan dokter saat memberi layanan pada pasien. Tingkat reliability dapat dibuktikan dan diukur serta digambarkan oleh petugas Rumah Sakit Umum Daerah(RSUD) Kota Dumai dalam melayani masyarakat atau pasien dirawat jalan Rumah Sakit.

Untuk itu dapat dilihat melalui pernyataan/jawaban pasien (informan) kepada peneliti saat mewawancara dengan beberapa orang informen.

Menurut Bapak Nazir yang memeriksakan diri ke poliklinik gigi beliau mengatakan "Dokter dalam melayani sangat baik, diagnosa penyakit saya sangat tepat, pertama saya datang kesini untuk memeriksakan penyakit gusi saya dan dilayani 
dokter, dokter bilang penyakit saya harus di operasi dan minggu depannya langsung operasi dan sekarang saya control untuk melihat perkembangan penyakit saya”. (wawancara dengan bapak Nazir tanggal 27 April 2020 pukul 10.30 WIB).

Menurut ibu weny yang memerikasakan diri ke poliklinik kebidanan beliau mengatakan "saya sudah 3 kali berobat disini penyakit saya sudah agak membaik tetapi kadang masih kambuh juga, setiap kali kambuh saya hanya minum obat yang sudah diresepkan dokter”

(wawancara.dengan ibu weny tanggal 27 April 2020 pukul 10.45 WIB).

Berdasarkan hasil wawacara dengan para informan jika dilihat dari aspek reliability pelayanan yang ada di rawat jalan poliklinik Rumah Sakit Umum Daerah(RSUD) Kota Dumai sudah cukup bagus, diketahui bahwa pernyataan dari informan/narasumber mengatakan pada dasarnya diagnosa yang dibuat oleh dokter spesialis hampir semuanya tepat sesuai dengan gejala dan keluhan pasien, hanya sebagian ada beberapa dokter yang belum dapat mengetahui dengan persis diagnosa penyakitnya, tetapi dalam pelayanan yang diberikan dokter dan petugas poliklinik gigi dianggap pasien memuaskan.

Berdasarkan pendapat Sinambela (2008: 3-5) mengatakan setiap manusia membutuhkan pelayanan, apalagi secara berlebihan dikatakan kalau pelayanan tidak bisa dipisahkan dalam kehidupan manusia. Pelayanan publik merupakan pemberian layanan (melayani) kebutuhan orang atau masyarakat yang memiliki kepentingan dalam organisasi berdasarkan pada aturan dan tata cara yang telah ditetapkan.

Selain itu menurut parasuman, dkk dalam Tjiptono, (2016:137), aspek yang terdapat dalam pemahaman konsumen terhadap kualitas pelayanan jasa termasuk didalamnya aspek reliability, yaitu aspek yang mengukur keandalan suatu pelayanan jasa kepada konsumen. Keandalan diartikan sebagai kemampuan dalam memberi pelayanan dijanjikan dengan terpercaya dan akurat. Karena berpengaruh pada janjang serta ragam pendidikan, tingkat keahlian dan tingkat profesionalnya petugas. Dari dimensi keandalan pasien bisa mengukur seberapa baik petugas rumah sakit dalam memberikan pelayanan. Sebenarnya kualitas pelayanan tidak dapat dinilai berdasarkan sudut pandang penyedia pelayanan tetapi juga harus dipandang dari sudut pandang pengguna jasa.

Secara umum aspek reliability yang ada pada Rumah Sakit Umum Daerah (RSUD) Kota Dumai dinilai sudah baik, dan semoga dapat ditingkatkan lagi. Memang pada dasarnya diagnosa yang dibuat oleh dokter spesialis di Rumah Sakit Umum Daerah (RSUD) Kota Dumai hampir semuanya tepat sesuai dengan keluhan dan masalah yang dihadapi pasien, hanya terdapat beberapa dokter saja yang tidak tahu pasti dengan diagnosa penyakitnya, Pelayanan dokter spesialis dan perawat pada Rumah Sakit Umum Daerah (RSUD) Kota Dumai dianggap informan (Pasien) sudah cukup memuaskan.

Berdasarkan data yang didapat menurut penulis dikaitkan terhadap teori dapat penulis simpulkan, bahwasanya aspek reliability kualitas pelayanan rawat jalan pada Rumah Sakit Umum Daerah (RSUD) Kota Dumai di nilai baik, karena untuk memberikan keandalan sebagai kemampuan untuk memberikan jasa/pelayanan yang dijanjikan dengan terpercaya dan akurat oleh petugas sudah bisa dilaksanakan dengan baik.

\section{Dimensi Responsiveness (Daya tanggap)}


Responsiveness adalah kesediaan petugas Rumah Sakit dalam membantu serta melayani pelayanan dengan cepat dan tepat pada pasien yaitu seperti ketangkasan perawat dan dokter dalam melayani pasien, petugas memberikan semua informasi yang berhubungan dengan masalah pasien. Daya tanggap adalah dimensi yang memiliki sifat yang dinamis.

Dari pengamatan dan wawancara yang penulis lakukan pada pasien rawat jalan rsud kota dumai, Menurut Bapak Wan 60 tahun berobat di poli syaraf beliau mengatakan "saya datang dari jam 6 pagi untuk ambil nomor antrian dilayani di bagian pedaftaran jam 7, agak lama saya menunggu karena nomor antrian saya nomor 72 dan pendaftaran memanggil nomor itu 10 orang setiap beberapa menit, dokter juga lama datangnyaa, saya baru dilayani jam 11, saran saya untuk rumah sakit agak dipercepat pelayanannya biar masya-rakat tidak kelamaan menunggu" (Wawancara dengan Bapak Wan Pada 9 December 2019 pukul 11.50 WIB).

Menurut mereka ketanggapan waktu pelayanan yang diberikan petugas di rawat jalan sangat lama mulai dari bagian pendaftaran sampai waktu tunggu menerima pelayanan dari dokter spesialis. Berdasarkan Kepmenkes RI No.129/Menkes/SK/IV/2008 pada pelayanan rawat jalan untuk indicator waktu tunggu pelayanan di rawat jalan yaitu $\leq$ 60 menit dimulai dari pasien mendaftar sampai diterima/dilayani oleh dokter spesialis . Hal ini sama dengan tanggapan dari pihak rumah sakit yaitu kepala ruangan rawat jalan Rumah Sakit Umum Daerah(RSUD) Kota Dumai , yakni keluhan dari masyarakat yang datang dirawat jalan ini rata-rata adalah lama nya mereka menunggu untuk menerima pelayanan.

Secara umum dilihat dari aspek responsiveness kualitas pelayanan yang ada di
Rumah Sakit Umum Daerah(RSUD) Kota Dumai belum baik dan masih perlu perbaikanperbaikan ke arah lebih profesional lagi. Dilihat dari dimensi responsiveness diketahui bahwa sebagian petugas menurut masyarakat dalam memberikan pelayanan belum cukup responsif.

Berkaitan dengan pernyataan Parasuman, dkk dalam Tjiptono (2016:137) dimensi-dimensi yang berkaitan dengan pemahaman konsumen terhadap kualitas pelayanan diantaranya merupakan aspek responsiveness, dimana aspek ini adalah kemauan untuk membantu dan memberikan jasa dengan cepat kepada konsumen yang meliputi kesiapan tenaga kerja dalam menangani transaksi dan penanganan atas masalah yang di hadapi konsumen. responsiveness adalah dimensi bersifat paling dinamis. Ini dikarenakan dipengaruhi kemajuan teknologi. Sebagai contoh aspek respon-siveness dalam pelayanan adalah seberapa cepat dalam melayani.

Menurut Ovreveit dan Nurcahaya (2007:4) kualitas layanan kesehatan terdiri dari kualitas menurut konsumen (yang berkaitan dengan apakah pelayanan yang diberikan sesuai dengan yang diharapkan pasien).Kualitas profesional (berkaitan dengan pelayanan yang memenuhi kebutuhan pasien/masyarakat sesuai dengan diagnosa oleh para profesional), dan kualitas manajerial (berkaitan dengan apakah jasa yang diberikan dikerjakan tanpa pem-borosan dan kesalahan, dengan harga terjangkau, serta sesuai peraturan resmi dan peraturan lainnya).

Berdasarkan pernyataan-pernyataan teoritis tersebut jika dikaitkan dengan permasalahan yang ditemukan dilapangan yang mengatakan sebagian masyarakat mengeluhkan lamanya waktu tunggu 
pelayanan yang di berikan petugas pendaftaran sampai dilayani dokter specialis.

Menurut peneliti bagian pendaftaran memang terhitung lama dalam mendaftarkan pasien untuk menuju poli-poli yang di tuju dikarenakan saat pendaftaran bergantung pada koneksi internet, dan menunggu bagian rekam medis untuk mengambilkan data pasien yang sebelumnya pernah berobat di Rumah Sakit Umum Daerah (RSUD) Kota Dumai dan dokter spesialis lama dalam memberi pelayanan dikarenakan harus mengunjungi pasien yang di rawat inap dulu setelah selesai mereka baru menuju rawat jalan untuk memeriksa pasien di rawat jalan, tetapi berdasarkan Kepmenkes RI No.129/Menkes/SK/IV/2008 pada pelayanan rawat jalan untuk indicator waktu tunggu pelayanan di rawat jalan yaitu $\leq 60$ menit dimulai dari pasien mendaftar sampai diterima/dilayani oleh dokter spesialis.

Dimensi responsiveness dapat peneliti menafsirkan sesuai dengan teori, rumah sakit yang cepat tanggap adalah yang mau melakukan beragam cara untuk mengenali, melayani serta memenuhi kebutuhan dan harapan pasien. Maka sebaiknya rumah sakit bisa memperkirakan seresponsif apa dirinya serta menentukan cara meningkatkan kinerjanya dalam menghasilkan kepuasan pasien.

Dari uraian diatas serta dengan data yang diperoleh dikaitkan dengan teori yang digunakan, penulis menarik kesimpulan bahwa keterkaitan dengan dimensi responsiveness kualitas pelayanan rawat jalan pada Rumah Sakit Umum Daerah (RSUD) Kota Dumai dinilai masih belum baik, ini dikarenakan lamanya masyarakat menunggu dibagian pendaftaran dan lamanya waktu tunggu untuk dilayani dokter spesialis di Rumah Sakit Umum Daerah (RSUD) Kota Dumai.

\section{Dimensi Asurance (Jaminan)}

Asurance adalah jaminan serta kepastian yaitu berupa pengetahuan, kesopan santunan, kesabaran, keramahan serta kemampuan petugas Rumah Sakit dalam menumbuhkan rasa percaya pasien pada rumah sakit. Aspek assurance meliputi beberapa komponen antara lain komunkasi, jaminan, keamanan, keterampilan serta sikap sopan santun.

Dari yang penulis temukan dilapangan yang mengatakan bahwa sebagian petugas Rumah Sakit Umum Daerah (RSUD) Kota Dumai, lumayan sabar dan ramah dalam melayani dari petugas ,perawat sampai dokter yang menangani masyarakat yang datang ke setiap poliklinik rawat jalan, petugas dan perawat sangat komunikatif dalam memberikan pelayanan, dan terlihat hanya beberapa petugas atau perawat yang masih hanya sekedar melayani dan jarang berkomunikasi dengan masyarakat.

Menurut ibu ita yang memeriksakan dirinya dirawat jalan poliklinik kebidanan beliau mengatakan "petugas dan perawat di poliklinik rumah sakit umum daerah kota dumai ini dalam melayani cukup ramah dan sopan tetapi ada beberapa petugas yang saya kurang senyumnya serta kurang komunikatif dalam memberikan informasi jadi saya kebingungan dan harus bertanya ke petugas lain yang lebih perhatian dan mau mengarahkan tahap selanjutnya untuk memeriksakan diri”. (wawancara dengan ibu ita Pada 27 April 2020 pukul 11.00 Wib).”

Berkaitan dengan pernyataan parasuman, dkk dalam Tjiptono (2016:137), ukuran kualitas yang menjadi kesan kepada konsumen tentang kualitas pelayanan jasa salah satunya merupakan aspek assurance. Aspek ini merupakan ukuran kualitas 
pelayanan yang berkaitan pada keahlian dalam menimbulkan kepercayaan serta keyakinan pada konsumen. ukuran assurance atau kepastian meliputi kompetensi tenaga kerja pada pengetahuan produk mencangkup kemampuan petugas pada pengetahuan terhadap produk secara tepat, karamahtamahan, perhatian dan kesopanan saat melayani konsumen, keterampilan memberikan keamanan dalam memanfaatkan pelayanan yang ditawarkan dan keterampilan dalam menumbuhkan rasa percaya konsumen pada jasa yang diberikan, termasuk jasa pelayanan rumah sakit.

Sejalan dengan pendapat azwar (2002:18) mengemukakan kualitas pelayanan kesehatan pada rumah sakit adalah fenomena, karena ukuran dan indikatornya bisa berbeda pada orang yang terlibat dalam pelayanan kesehatan, dalam memuaskan kebutuhan dan tuntutan pemakai jasa pelayanan.

Aspek assurance pada kualitas pelayanan Rawat Jalan Rumah Sakit Umum Daerah (RSUD) Kota Dumai terbilang cukup baik serta pada aspek assurance diketahui bahwasanya petugas dalam melayani cukup sabar serta ramah saat melakukan pelayanan tetapi ada beberapa pegawai yang terlihat belum menunjukan sifat ramah dan komunikatif terhadapt pasien atau masyarakat yang datang ke rawat jalan Rumah Sakit Umum Daerah (RSUD) Kota Dumai. Petugas Rumah Sakit Umum Daerah (RSUD) Kota Dumai menjelaskan jika seandainya ada petugas kurang ramah dan komunikatif dalam melayani pasien atau masyarakat itu dikarenakan tergantung dari sifat individu seseorangnya.

Kualitas Pelayanan Rawat jalan pada Rumah Sakit Umum Daerah (RSUD) Kota Dumai dilihat dalam aspek assurance dapat dikatakan baik, kualitas pelayanan dari aspek assurance berhubungan dengan keahlian petugas menimbulkan kepercayaan serta keyakinan pada pasien seperti kesopanan serta keramahan saat melakukan pelayanan, ini dianggap masayarakt sudah sangat baik.

\section{Dimesi Empathy (Empati)}

Dimensi empathy merupakan aspek yang menekankan pada perhatian kepada konsumen serta bersifat individu kepada masyarakat untuk lebih mengetahui harapan atau kebutuhan masyarakat. Dimensi empathy berkaitan bagaimana petugas menanggapi keluhan dan masalah pasien, dan bagaimana petugas bisa mengenali pasien dengan baik. empathy sangat memerlukan sentuhan perasaan pribadi, aspek empathy merupakan aspek yang dapat menjadi kesempatan besar dalam membentuk pelayanan berbeda berupa suatu yg tidak diharapkan pasien tetapi diberikan oleh rumah sakit.

Dari aspek empathy diketahui bahwa tidak semua petugas rawat jalan Rumah Sakit Umum Daerah (RSUD) Kota Dumai mau memberikan perhatian lebih kepada masyarakat yang datang untuk memerikasakan diri dan tidak semua keluhan pasien direspon oleh petugas/perawat tetapi menurut pihak rsud mereka menyatakan petugas yang ada di Rumah Sakit Umum Daerah (RSUD) Kota Dumai petugas/perawat rawat jalan selalu meminta pasien menyampaikan keluhan saat melakukan pemeriksaan serta keluhan yang disampaikan selalu ditanggapi.

Berkaitan dengan pernyataan Parasuman dkk dalam Tjiptono (2016:137) dmensi-dimensi yang mewakili persepsi konsumen terhadap suatu kualitas pelayanan jasa termasuk diantaranya adalah dimesi empathy, dimensi empathy merupakan kesediaan petugas untuk peduli dan memberikan perhatian pribadi kepada 
pengguna jasa. Pelayanan yang empathy sangat memerlukan sentuhan/perasaan pribadi. Dimensi empathy adalah dimensi yang memberikan peluang besar untuk menciptakan pelayanan yang mengejutkan yaitu sesuatu yang tidak di harapkan pengguna jasa tetapi tenyata di berikan oleh penyedia jasa.

Berkaitan dengan pelayanan kesehatan menurut Azwar dalam aprilia (2008:17) yang menyatakan bahwa batasan dalam kesehatan yang bermutu adalah pelayanan kesehatan yang dapat memuaskan setiap pemakai jasa sesuaii dengan tingkat kepuasan rata-rata penduduk, serta penyelenggaraannya sesuai kode etik dan standar yang telah di tetapkan.

Kualitas pelayanan pada rumah sakit adalah sebuah peristiwa yang unik, sebab dimensi dan indikatornya bisa berbeda antara orang dengan yang lain saat memberikan pelayanan kesehatan.

Dari hasil observasi dilapangan dapat diketahui tidak semua perawat/petugas rawat jalan Rumah Sakit Umum Daerah (RSUD) Kota Dumai mau menanyakan keluhan pasien saat memberikan pelayanan serta beberapa keluhan saja yang di sampaikan pasien yang di tanggapi oleh petugas, dari sini dapat peneliti analisis aspek empati pada petugas rumah sakit tergantung pada sifat petugas itu sendiri ada perawat yang aktif dan ada yang tidak serta ada yang peduli dan yang tidak terhadap pasien.

Kualitas Pelayanan Rawat jalan pada Rumah Sakit Umum Daerah (RSUD) Kota Dumai dilihat dalam aspek empathi dinilai masih belum baik, kualitas pelayanan dari aspek emphatic ini berkaitan pada sifat individu seseorang dalam memberikan perhatian yang tulus serta menanggapi masalah atau keluhan pada pasien ini masih dianggap masyarakt belum baik dikarenakan berdasarkan observasi peneliti ini semua di sebabkan oleh petugas /perawat yang dianggap kurang peka dan kurang peduli dengan pasien.

\section{SIMPULAN DAN SARAN}

Kualitas pelayanan rawat jalan pada Rumah Sakit Umum Daerah (RSUD) Kota Dumai belum dapat dikatakan berkualiats dikarenakan dari lima dimensi kualitas pelayanan, hanya dimensi Reliability (keandalan) dan Assurance (jaminan) yang dinilai baik, dan dimensi Tangible, Responsiviness, dan Empathy belum berjalan dengan baik.

Dari hasil kesimpulan penulis memberikan beberapa saran yaitu :

1) Pihak Rumah Sakit Umum Daerah (RSUD) Kota Dumai perlu membuat atau merencanakan tempat parkir cukup luas untuk masyarakat yang datang memeriksakan diri ke rawat jalan poliklinik Rumah Sakit Umum Daerah (RSUD) Kota Dumai agar tidak ada mobil atau motor yang parkir di pinggir jalan, karna dapat mengganggu masyarakat yang lewat. Serta petugas cleaning service lebih memperhatikan kebersihan kamar mandi dan WC setiap hari.

2) Pelayanan dokter dan petugas, Rumah Sakit Umum Daerah (RSUD) Kota Dumai masih harus dimaksimalkan lagi, serta jumlah dokter disesuaikan lagi dengan rumah sakit tipe $B$ dan hendaknya keluhan pasien lebih ditanggapi, sehingga mereka merasa puas pada pelayanan yang diberikan.

3) Untuk Waktu tunggu pelayanan yang diberikan baik petugas pendaftaran maupun dokter specialis sekiranya harus di sesuaikan lagi dengan Standar 
Pelayanan Minimal menurut Kepmenkes RI No.129/Menkes/SK/IV/2008

4) Dokter maupun perawat di Rumah Sakit Umum Daerah (RSUD) Kota harus benar-benar mencari tahu keluhan pasien dan tidak membeda-bedakan pasien yang menggunakan BPJS atau pasien Umum.

\section{DAFTAR PUSTAKA}

Azwar, A. (2002). Pengantar Aministrasi Kesehatan. Edisi Ketiga. Jakarta: PT Bina Aksara.

Hartono, Bambang. (2010). Manajemen Pemasaran untuk Rumah Sakit. Jakarta: Rineka Cipta.

Hardiyansyah, (2018). Kualitas Pelayanan Publik, Yogyakarta : Gava Media

Mukarom, Zaenal dan Muhibudin Wijaya. (2015). Manajemen Pelayanan Publik. Bandung: CV. Pustaka Setia

Patilima, Hamid. (2007). Metode Penelitian Kualitatif. Bandung : Alfabeta.

Pujiyono, (2016). Strategi Peningkatan Kualitas Pelayanan Instalasi Rawat Jalan RSUD dr. Darsono Kabupaten Pacitan 2016, Tesis, Magister Manajamen, STIE Widya Wiwaha, Yogyakarta.

Sinambella, dkk. (2008). Reformasi Pelayanan Publik, Cetakan Keempat. Jakarta: Bumi Aksara.

Tjiptono, Fandy dan Gregorius Chandra, (2016), Service, Quality and Satisfaction Edisi 4. Yogyakarta: Andi.
Keputusan Menteri Kesehatan Republik Indonesia Nomor: 129/MENKES/ SK/II/2008 tentang Standar Pelayanan Minimal Rumah Sakit.

Peraturan Walikota Nomor 42 Tahun 2008 Bab 2 Pasal 2 \& 3

Pasal 29 huruf b Undang Undang No 44 Tahun 2009

Undang Undang No 44 Tahun 2009 tentang Rumah Sakit

Undang-Undang Republik Indonesia Nomor 25 Tahun 2009 